\title{
TEACHING ASSISTANT TRAINING IN ENGINEERING DESIGN
}

\author{
Justine Boudreau and Hanan Anis \\ University of Ottawa \\ jboud030@uottawa.ca, hanis@uottawa.ca
}

\begin{abstract}
The Faculty of Engineering at the University of Ottawa is home to multiple rapid prototyping facilities and entrepreneurship spaces. These include a makerspace, a machine shop and a design space for any student to use free of charge. First- and second-year students also take courses in the Makerlab, a sister facility to the Makerspace, that introduces them to collaborative project-based learning, engineering problem-solving and prototyping in a cornerstone design course. Each three-hour weekly lab has a teaching assistant (TA), typically a graduate student, and a project manager (PM), typically an undergraduate student who has taken the course previously. They are responsible for teaching the lab content and guiding the students through their design process. Since design courses are weighted heavily toward projects and labs, this evidence-based practice paper is part of a study that has the goal of understanding, via student evaluations, the impact of TA and PM training on their performance. This paper presents an analysis of the impact of TA and PM training, based on the students' evaluation of their TA's and PM's performance. Factors considered were the amount of training received by the TAs and PMs, the type of training and the satisfaction of the students. The students were surveyed to gauge their satisfaction with the quality of their TAs and PMs, and the survey results were compared with a number of outcomes.
\end{abstract}

Keywords: Teaching Assistant Training, Engineering Design, Makerspaces, Project Based Learning.

\section{INTRODUCTION}

Teaching assistants (TAs) are important in the undergraduate teaching structure in higher education in North America [1]. They are responsible for grading and for leading tutorials and labs of various subjects. Unlike elementary or secondary school teachers, graduate students are often thrown into teaching without much training or practice [2], [3]. In addition, engineering design is complex and not a straightforward subject to teach [4]. In the past, TAs have generally developed skills focused only on content delivery; however, "preparing TAs should involve practical hands-on training that includes mentoring, monitoring, institution-wide resources, departmental training, course-level discussions, and support from instructors and peers." [5, p. 86] They need to develop a variety of skills that will be useful for them in the future in academia or other sectors. Since academia is research-focused, tension with the teaching side can cause departments to ignore training for TAs to be good teachers and under-prepare them for their roles as TAs or as future faculty members [6] .

Training programs are becoming more common for graduate students in universities. New programs being implemented across North America now include design theory, teaching and mentoring [3]. In design, since there are many possible outcomes to one given problem, the TAs must be trained to guide students through the design process. The University of Victoria argues that TAs have many roles, including mentor, educator, adviser and coinstructor, but that the mentor role is the most important when it comes to design projects [3]. TAs are extremely important in this context in terms of encouraging positive group dynamics, individual and team innovation and problem-solving, essentially acting as coaches [7].

This paper outlines the University of Ottawa's new selection and training program for TAs and project managers (PMs) in a first- and second-year engineering design course, and assesses its impact based on the results of student evaluations of the performance of their TAs and PMs. 


\section{COURSES}

\subsection{Course Structure}

Engineering students at the University of Ottawa are exposed to engineering design in first- and second-year courses. The first-year engineering design course, called Engineering Design, is mandatory for first-year mechanical, biomedical mechanical, electrical and civil engineering students. The second-year engineering design course, called Introduction to Product Development and Management for Engineers and Computer Scientists, is open to all departments of engineering as well as computer scientists from different years. The focus of both courses is on client-centred design, where groups of students work on a specific client's problem or needs during one semester and deliver a final physical prototype. Groups are formed from multidisciplinary and multi-year engineering or computer science students within the first two weeks of class. The first assignment for the first week of class is a personality assessment, and with that information, the students are typically instructed to form groups of four to six members by finding diverse team members to complement themselves in terms of personality and program.

The two main components of the courses are the lectures and the labs. In the lectures, the students learn design methodologies, processes for product development, and time and project management. Students in the second-year course also learn about business models, economics and marketing. The students put these skills to use in their own semester-long project. Each section of the first-year course works for the same client on the same project, which is different from the other sections. In the second-year course, the students are given a list of projects from various clients and asked to choose their top three. The professors then distribute projects so as not to have more then two teams working on the same one.

Each team meets their client a minimum of three times during the semester. The first-year course meetings are either in the classroom or lab, and the students in the second-year course meet their client wherever is most convenient for the client. The first meeting with their client, in the third week of the semester, is used to determine specific needs for the project. The teams then develop metrics and concepts before meeting the client a second time to get feedback. Next is the start of prototype iteration cycle, where the students use facilities like a makerspace and a machine shop to make three or more prototypes to get to their final product. These are two of seven student spaces hosted by the Centre for Entrepreneurship and Engineering Design (CEED). A third client meeting is held after the first prototype is completed to receive more feedback on the product features and functionality. The client is then presented the final product at Design Day at the end of the semester, a showcase featuring all the cornerstone engineering design teams.

The work is done mostly at home, with some lab time dedicated to working on the project. The rest of the labs are designed to teach the necessary skills to the students to be able to do their projects or to give them enough of an introduction that they are able to learn more by themselves if needed. Skills in first year include Solidworks, Matlab, laser cutting and one lab that varies to teach something project-specific. In second year, students learn 3D printing, PCB design, mobile app development, lathe and mill. In addition, common to both is Arduino, soldering and sheet metal work. The labs of the second-year course are done with the specific goal of making parts for a small smartphone-controlled car that is assembled in one of the last labs. All labs take place in the Makerlab, which is a sister facility to the Makerspace. The following table outlines the labs done in both courses.

Table 1. First- and second-year labs

\begin{tabular}{|l|l|l|}
\hline Week & First year & Second year \\
\hline 1 & Microsoft & Basic training \\
\hline 2 & Arduino & Lathe/mill \\
\hline *Extra & Lathe/mill \\
\hline 3 & Project-specific lab & Client meeting 1 \\
\hline 4 & Project work & Arduino + 3D printing \\
\hline 5 & Basic training & Client meeting 2 \\
\hline 6 & $\begin{array}{l}\text { Solidworks + Client } \\
\text { meeting 2 }\end{array}$ & $\begin{array}{l}\text { Presentations + intro } \\
\text { to soldering }\end{array}$ \\
\hline 7 & Matlab & Client meeting 3 \\
\hline 8 & $\begin{array}{l}\text { Soldering + laser } \\
\text { cutting }\end{array}$ & $\begin{array}{l}\text { PCB design + project } \\
\text { work }\end{array}$ \\
\hline 9 & $\begin{array}{l}\text { Project work } \\
\text { Mobile app + chariot } \\
\text { assembly }\end{array}$ \\
\hline 10 & Project work & Project work \\
\hline 11 & $\begin{array}{l}\text { Project work/Design } \\
\text { Day }\end{array}$ & $\begin{array}{l}\text { Project work/Design } \\
\text { Day }\end{array}$ \\
\hline 12 & $\begin{array}{l}\text { Client meeting 4 + } \\
\text { paperwork }\end{array}$ & $\begin{array}{l}\text { Client meeting 4 + } \\
\text { paperwork }\end{array}$ \\
\hline
\end{tabular}


The theme for the first-year course changes almost every semester and is different between sections. The theme for the second-year course is always accessibility. This means students work on projects like wheelchair skis, portable wheelchair ramps and foot-controlled guitars. Clients are diverse, ranging from individuals to organizations like hospitals, and have different needs.

Each lab has a teaching assistant (TA) and a project manager (PM) who are present every week. The TA is typically a graduate student, and the PM is typically an undergraduate student who has taken the course before. The TA has an added responsibility of marking the submissions by the students. Both the TA and the PM act as guides and mentors to the groups as they go through their design process and learn the skills necessary to do so. Both sit together at the end of the semester and evaluate each student in their lab based on their contribution to the project over the semester. The students also evaluate their TA and PM at the end of the semester.

Each group also does a peer and team assessment twice in the semester using a tool developed by the Individual and Team Performance (ITP) Lab at the University of Calgary [8]. The first evaluation happens in the sixth week of the term, so the groups are able to receive feedback from their teammates and improve on their work before most of the heavy prototyping happens. It is also used by the professor, TA and PM to catch the groups that need extra help or an intervention to resolve group problems. The second evaluation happens at the end of the term and is used to weigh the final project grades based on the contribution from each member.

\subsection{TA and PM Training Program}

A training program has been developed for the TAs and PMs to adequately prepare them to be of most use to the students and teams in the design courses. The hiring and training practices have evolved through continual improvement over the years that the courses have run.

After the winter 2019 semester, the first-year course had run four times. The first semester, in winter 2017, had one TA per lab section, chosen based on their skills listed in the TA application to the faculty. There was one exception: one section of the course had a PM because it was deemed to be a more difficult project. In this semester, the limit on the number of students in each lab was high, so some labs had over 30 students. (Labs are now capped at 24 students.) The second time the course was offered, in winter 2018, there was again one TA per section chosen based on the information in their applications. However, there was also one PM in each lab to accompany the TA. These PMs were chosen from students in previous semesters of the first- or second-year design courses who were identified as leaders who had done well in the course. PMs were added to address the general lack of technical and design process knowledge of the TAs as well as simply to provide more support for the students because it is a complex course with a heavy work load. Since the PMs have taken the course, they are familiar and experienced with the Makerspace technology and machine shop tools. For the winter 2018 course, all the TAs and PMs were encouraged to practise the labs before doing them with the students, but they were not supervised and it was not checked if they had practised. The only formal training given was machine shop basic training (sheet metal work).

Winter 2019 marked the seventh time that the secondyear course was run. The first pilot run in winter 2016 had only eight students, and one PM, who was a current Makerspace staff, was assigned to help them. When the course was launched at a larger scale in fall 2016, there were two PMs per lab section, and the TA was responsible only for marking. Only two of the PMs had taken the course before; the rest were Makerspace staff. The TA was selected based on the TA application process through the faculty. In the following five semesters (winter, summer and fall 2017, winter and summer 2018), there were also two PMs per lab, with TAs who were marking only. The PMs were mainly students who had taken the course, because that number of students was growing. Training for the PMs was limited to practising the labs before having to teach them, since the PMs were already familiar with the material. Similar to the first-year course, the only formal training was for the machine shop equipment (sheet metal, mill and lathe).

Practices changed in fall 2018 for both courses to improve the success of the teams by better preparing the people who spend the whole semester helping the students with their technical and team management skills. TAs were selected for an interview based on their application and chosen based on leadership, technical skills and motivation. Many PMs continued from the previous semesters, but the new ones were interviewed and chosen again based on leadership, technical skills and motivation. Unlike the previous terms, there was mandatory technical and non-technical training for all staff (TAs and PMs). 
Technical training was provided on all the lab resources, including 3D printing, laser cutting and soldering. Non-technical included project and conflict management, coaching and a session on design for manufacturing. The same training was provided in winter 2019. The following lists the items covered during the new TA and PM training.

- Technical:

○ Arduino

- Laser cutting

- 3D printing

$\circ \quad$ Soldering

- Basic training (sheet metal work)

○ Mill

- Lathe

- Lab course-specific skills (PCB design and Solidworks)

- Non-technical:

- Course orientation

- Makerepo + Makerstore

- Project and conflict management

- Coaching

- Design for manufacturing

Each new semester, there is a larger pool of people with technical experience because they have either gone through one or two of the design courses or they use the Makerspace for personal or other school projects. This is especially helpful when looking for TAs who have more useful knowledge for these specific courses. Students who excel in the course also have better non-technical skills like communication and project management. Since the pool of students who have taken the course is growing, it is also easier to find better PMs - so much so, that it gets harder to narrow down people with each new round of interviews.

Since the course load is heavy and there are many details to pay attention to, a formal course orientation was added to mitigate some of the confusion. All of the design groups are also required to post their projects on a projectsharing website (makerepo.com) hosted and managed by the Centre for Entrepreneurship and Engineering Design (CEED). The website includes a user management system for users to sign in to all prototyping spaces hosted by CEED and keep track of completed training. Students can buy the various components they need for their projects through the Makerstore; therefore the TAs and PMs were also trained on how to show students how to make purchases for the courses.
To emphasize to the staff the importance of project and conflict management and of identifying problems in the student groups, one of the course professors held a training session on managing projects and conflicts. To address the need for student and team mentorship to achieve better participation, learning and quality projects, a staff coaching session was introduced. This was based on the material developed by the University of Victoria [7]. Finally, it was noticed that the groups didn't always know what resources existed in the facilities, which caused them to manufacture a part of their project with a piece of equipment that was not necessarily appropriate. They also had a tendency to try to fabricate parts that should be bought, like fasteners. Therefore, a session on design for manufacturing was provided to the TAs and PMs to highlight past practices that could be improved and give them more knowledge about preparing designs based on available manufacturing methods.

The number of students participating in the courses has also changed. The TA allocation is generally 30 students for one TA, which has been constant. However, in winter 2018, PMs generally did only one lab section. This meant there were more people to keep on the same page and share information with them. Therefore, in fall 2018, PMs were assigned to two or three labs so they could get more experience and so the courses could become more consistent.

Since summer 2017, there has also been a lab manager for the Makerlab, in an attempt to keep the content and the staff roles unified across class sections. In addition, the lab manager works on course improvements and ensures the staff are prepared for what is expected from them.

\section{METHODS}

\subsection{Research Questions}

This paper aims to determine the effect of the new training program and the results are used to answer the following research questions:

RQ1: Does the average score of a person depend on their role (TA or PM) in each semester separately (winter/fall 2018/winter 2019)?

RQ2: Are the average scores of the two roles significantly different?

RQ3: Does the average score of one group (TA or PM) depend on the semester (winter/fall 2018/winter 2019)? 


\subsection{Student Evaluation}

Surveys were distributed to evaluate how the TAs and PMs were performing in the eyes of the students of both courses. The first survey was at the end of the winter 2018 semester, evaluating only PMs. Next, in the fall 2018 and winter 2019 semesters, both TAs and PMs were evaluated. Students from both the first- and second-year courses completed the survey. Items on the survey included evaluating equipment proficiency, problemsolving, preparedness, attitude, etc., on a scale of 1-4, with a total of 14 items. (See Appendix A.) The survey results represent the students' impressions of the TAs and PMs over the semester therefore all survey items will be used in the analysis. Finally, in winter 2019, the survey was also sent to students from the winter 2018 courses asking them to evaluate their TAs to attempt to recover more data from that term.

\section{RESULTS AND DISCUSSION}

The winter 2018 survey evaluated 21 PMs and had a total of 351 responses (41\% of students). Since this original survey included only PMs, another survey with the same questions was sent to students who had taken the class during that semester to evaluate the 11 TAs. It was sent almost a year later; as a result, there were only 15 responses and 7 TAs were evaluated, likely because of the delay.

In fall 2018, the 10 PMs and 12 TAs were all included in the main survey, which had 358 responses $(52 \%$ of students).

The winter 2019 semester had 13 PMs, 12 TAs and 328 responses in the survey ( $46 \%$ of students).

To analyze the results, the scores from all the survey answers were added and all entries for a person were averaged.

To answer the first question, each semester was analyzed separately and a one-way analysis of variance (ANOVA) was conducted to determine if the average score was different based on the roles for the winter 2018 semester. The TAs $(\mathrm{n}=7,82.2 \pm 7.1)$ scored lower than the PMs $(\mathrm{n}=21,90.5 \pm 5.1)$. Data is presented as mean \pm standard deviation. There were no outliers, as assessed by boxplot; data were normally distributed for each group, as assessed by Shapiro-Wilk test ( $p>.05)$; and there was homogeneity of variances, as assessed by Levene's test of homogeneity of variances $(p=.327)$. Average survey scores were statistically significantly different between roles, $\mathrm{F}(1,26)=11.495, \mathrm{p}=0.002, \omega 2=0.27$. A KruskalWallis test was conducted to determine if there were differences in the average survey scores between the roles for the fall 2018 semester: TAs $(n=12)$ and PMs $(n=$ 10). Distributions of average scores were not similar for all groups, as assessed by visual inspection of a boxplot. Survey scores increased from TA (88.5) to PM (92.7) but were not statistically significant, $\chi^{2}(1)=1.739, \mathrm{p}=.187$. Again, a one-way ANOVA was conducted to determine if the average score was different based on the roles for the winter 2019 semester. The TAs $(\mathrm{n}=12,88.4 \pm 2.1)$ scored lower than the PMs $(n=13,92.5 \pm 1.2)$. Data are presented as mean \pm standard deviation. There were no outliers, as assessed by boxplot; data were normally distributed for each group, as assessed by Shapiro-Wilk test ( $p$ > .05); and there was homogeneity of variances, as assessed by Levene's test of homogeneity of variances ( $p$ $=.132$ ). Average survey scores were again not statistically significantly different between roles for this semester, $\mathrm{F}(1,23)=2.907, \mathrm{p}=0.102$.

These results indicate that there was a noticeable difference between the performance of the TAs and the performance of the PMs in winter 2018 but that the difference was no longer significant in the fall or the winter of 2019. This is a good indication that the new procedures and training program have had a positive effect on the TAs, given that their scores are closer to those of the PMs, who generally perform better. We can also observe that similar results came out of the fall 2018 and winter 2019 semesters, which indicates the initial success of the training program continued over a longer period and with many new people.

To answer the second question, another Kruskal-Wallis test was conducted to determine if there were differences in the average survey scores between the roles in all three semesters combined: TAs $(n=31)$ and PMs $(n=44)$. The distributions of average scores were similar for all groups, as assessed by visual inspection of a boxplot. Median survey scores were statistically significant between roles, $\chi^{2}(1)=7.120, p=.008$.

Looking at all the results from the three semesters combined shows that PMs score significantly higher than TAs. This leads to the conclusion that although training and selection processes have generally increased the scores of both groups, the TAs still need more support to reach the same level as the PMs. 
The third question addresses the differences of each role individually over the course of the semesters. A Kruskal-Wallis test was conducted to determine if there were differences in the average survey scores of PMs between semesters: winter $2018(n=21)$, fall $2018(n=$ 10) and winter $2019(n=13)$. The distributions of average scores were similar for all groups, as assessed by visual inspection of a boxplot. The survey scores increased from winter (91.0) to fall 2018 (93.4) and stayed relatively constant in winter 2019 (92.7) but were not statistically significant, $\chi^{2}(1)=2.935, \mathrm{p}=.230$. A one-way ANOVA was also conducted to determine if the average score of TAs was different between semesters. The TAs from the winter 2018 semester $(\mathrm{n}=7,82.2 \pm 7.1)$ scored lower than the TAs from the fall semester $(\mathrm{n}=12,88.5 \pm 7.1)$ and winter 2019 semester $(n=12,88.4 \pm 2.1)$. Data are presented as mean \pm standard deviation. There were no outliers, as assessed by boxplot; data were normally distributed for each group, as assessed by Shapiro-Wilk test ( $p>.05)$; and there was homogeneity of variances, as assessed by Levene's test of homogeneity of variances ( $p$ $=.949$ ). Average survey scores of TAs were not statistically significantly different between semesters, $\mathrm{F}(2$, 28) $=2.060, \mathrm{p}=0.146$.

The scores of both groups of people (TAs and PMs) did not change significantly between semesters; however, they did increase, which demonstrates that the intervention had a positive effect but that it was not enough for statistical significance. This may be a result of having more first-time TAs who still struggled with the course load and details and therefore may not have done as well as expected. As well, given that the PMs already scored very well, and so it would be harder for their scores to get much higher. Finally, the similarity between fall 2018 and winter 2019 shows the effectiveness of the training program over many semesters.

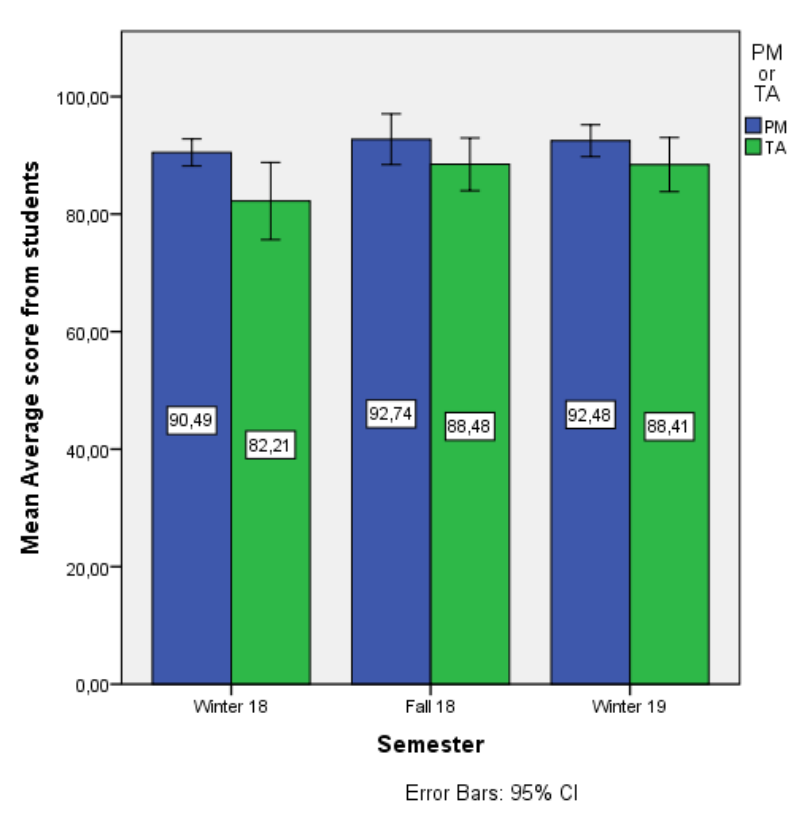

Figure 1. TA/PM scores in each semester

This dataset could be flawed because of the low number of respondents for the TAs of the winter 2018 semester. However, anecdotally, the results of the survey reflect the researchers' observations of the TAs.

\section{CONCLUSIONS}

Since the TAs and PMs play an important role in design courses, it is important that they are properly trained and prepared to guide the project teams and help them succeed. The new selection and training program delivered at the University of Ottawa attempts to give TAs and PMs more well-rounded training to meet the demands of the cornerstone engineering design courses. This includes technical (3D printing, laser cutting, etc.) and non-technical (coaching, conflict management, etc.) training sessions. Using students evaluations to compare the TA and PM performance in the winter 2018, fall 2018 and winter 2019 semesters found a significant difference in scores between TAs and PMs in the winter 2018 semester, which is consistent with observations that TAs had very little useful experience and PMs add a lot of value because they have previously taken the course. The student evaluations from the fall 2018 and winter 2019 semesters, however, after the new training program was implemented, showed no significant difference in the two roles. There was also an increase in average scores for both TAs and PMs between the winter and fall 2018 
semesters. This indicates that the training program was successful, since the general performance of the TAs and PMs has increased and the TAs' evaluations are approaching those of the PMs - a result that was repeated in a second semester.

\section{Acknowledgements}

Special thanks to Mohamed Galaleldin for help with some analysis details. These programs are possible thanks to the NSERC Chair in Entrepreneurial Engineering Design.

\section{References}

[1] K. N. Meadows, K. C. Olsen, N. Dimitrov, and D. L. Dawson, "Evaluating the Differential Impact of Teaching Assistant Training Programs on International Graduate Student Teaching," Canadian Journal of Higher Education, vol. 45, no. 3, pp. 34-55, 2015.

[2] C. R. Luebbering and K. N. Kolivras, "Commentary: The Precarious Position of Teaching as a Graduate Student," The Geographical Bulletin, vol. 51, pp. 111-118, 2010.

[3] F. Firmani, M. McWilliam, P. Wild, M. McGuire, N. Dechev, and C. Bradley, "TRAINING PROGRAM IN ENGINEERING DESIGN FOR GRADUATE TEACHING ASSITANTS," Proceedings of the Canadian Engineering Education Association, 2013.

[4] C. L. Dym, A. M. Agogino, O. Eris, D. D. Frey, and L. J. Leifer, "Engineering Design Thinking, Teaching, and Learning," Journal of Engineering Education, vol. 94, no. 1, pp. 103-120, 2005.

[5] M. A. Parker, D. Ashe, J. Boersma, R. Hicks, and V. Bennett, "Good Teaching Starts Here: Applied Learning at the Graduate Teaching Assistant Institute," Canadian Journal of Higher Education, vol. 45, no. 3, pp. 84-110, 2015.

[6] E. E. Shortlidge and S. L. Eddy, "The trade-off between graduate student research and teaching: A myth?," PLoS One, vol. 13, no. 6, p. e0199576, 2018.

[7] A. Dimopoulos, K. Bubbar, R. Gaetz, and P. Wild, "TRAINING TEACHING ASSISTANTS AS COACHES," Proceedings of the Canadian Engineering Education Association (CEEA), 2018.

[8] T. O'Neill et al., "Introducing a scalable peer feedback system for learning teams," Assessment \& Evaluation in Higher Education, pp. 1-15, Nov. 2018.

\section{APPENDIX A}

TA/PM evaluation survey questions and rubric

\begin{tabular}{|c|c|c|c|c|}
\hline & $\begin{array}{l}1 \text { (Un- } \\
\text { satisfactory) }\end{array}$ & $\begin{array}{l}2 \text { (Sub- } \\
\text { satisfactory) }\end{array}$ & 3 (Expectation) & 4 (Exceeds) \\
\hline \multicolumn{5}{|c|}{ General Lab Supervision } \\
\hline Punctuality & Always late & Mostly late & $\begin{array}{l}\text { Rarely late, } \\
\text { mostly on time }\end{array}$ & $\begin{array}{l}\text { Always on } \\
\text { time or early }\end{array}$ \\
\hline $\begin{array}{l}\text { Participation } \\
\text { in Cleaning } \\
\text { Routine }\end{array}$ & $\begin{array}{l}\text { Never unless } \\
\text { asked }\end{array}$ & $\begin{array}{l}\text { Rarely, with } \\
\text { reminder }\end{array}$ & $\begin{array}{l}\text { Cleans without } \\
\text { being asked }\end{array}$ & $\begin{array}{l}\text { Cleans above } \\
\text { and beyond }\end{array}$ \\
\hline $\begin{array}{l}\text { Create } \\
\text { Inclusive } \\
\text { Environment }\end{array}$ & $\begin{array}{l}\text { Dead inside, } \\
\text { sits in the } \\
\text { corner }\end{array}$ & $\begin{array}{l}\text { Limited } \\
\text { interaction and } \\
\text { meh }\end{array}$ & $\begin{array}{l}\text { Friendly, } \\
\text { positive attitude } \\
\text { while } \\
\text { interacting with } \\
\text { students }\end{array}$ & $\begin{array}{l}\text { Goes out of the } \\
\text { way to create } \\
\text { an inclusive } \\
\text { environment }\end{array}$ \\
\hline $\begin{array}{l}\text { Response to } \\
\text { Queries }\end{array}$ & $\begin{array}{l}\text { Stares off } \\
\text { blankly into } \\
\text { space }\end{array}$ & $\begin{array}{l}\text { With minimum } \\
\text { effort, directs } \\
\text { students to less } \\
\text { helpful } \\
\text { solution }\end{array}$ & $\begin{array}{l}\text { Actively } \\
\text { engages with } \\
\text { students and } \\
\text { helps direct } \\
\text { them to a } \\
\text { reasonable } \\
\text { solution }\end{array}$ & $\begin{array}{l}\text { Goes out of } \\
\text { their way to } \\
\text { find a solution } \\
\text { to a problem } \\
\text { that is brought } \\
\text { to their } \\
\text { attention }\end{array}$ \\
\hline $\begin{array}{l}\text { Equipment } \\
\text { Proficiency }\end{array}$ & $\begin{array}{l}\text { No } \\
\text { knowledge } \\
\text { of anything } \\
\text { in the } \\
\text { workspace }\end{array}$ & $\begin{array}{l}\text { Some to little } \\
\text { working } \\
\text { knowledge of } \\
\text { the equipment }\end{array}$ & $\begin{array}{l}\text { Is able to } \\
\text { convey their } \\
\text { working } \\
\text { knowledge to } \\
\text { students for } \\
\text { most of the } \\
\text { equipment }\end{array}$ & $\begin{array}{l}\text { Does research } \\
\text { on own time to } \\
\text { get to know } \\
\text { equipment } \\
\text { better }\end{array}$ \\
\hline $\begin{array}{l}\text { Problem } \\
\text { Solving }\end{array}$ & $\begin{array}{l}\text { Disregard for } \\
\text { assisting in } \\
\text { the problem } \\
\text { solving } \\
\text { process }\end{array}$ & $\begin{array}{l}\text { Tries to help } \\
\text { but gives up }\end{array}$ & $\begin{array}{l}\text { Able to provide } \\
\text { a solution } \\
\text { /information or } \\
\text { direct to another } \\
\text { source }\end{array}$ & $\begin{array}{l}\text { Goes above } \\
\text { and beyond to } \\
\text { help provide a } \\
\text { solution either } \\
\text { on their own }\end{array}$ \\
\hline
\end{tabular}

\begin{tabular}{|l|l|l|l|l|}
\hline \multicolumn{5}{|c|}{ Roles and Responsibilities } \\
\hline Prepared & $\begin{array}{l}\text { Is not able to } \\
\text { organize and } \\
\text { misses } \\
\text { elements }\end{array}$ & $\begin{array}{l}\text { Is prepared } \\
\text { but finishes } \\
\text { takss last } \\
\text { minute and } \\
\text { others are } \\
\text { not kept up } \\
\text { to date }\end{array}$ & $\begin{array}{l}\text { Ensures all } \\
\text { people } \\
\text { involved are } \\
\text { informed and } \\
\text { prepared ahead } \\
\text { of time }\end{array}$ & $\begin{array}{l}\text { Goes above and } \\
\text { beyond to } \\
\text { prepare and is } \\
\text { ready for last } \\
\text { minute changes } \\
\text { if necessary }\end{array}$ \\
\hline Communication & $\begin{array}{l}\text { Does not } \\
\text { communicate } \\
\text { well; unable } \\
\text { to } \\
\text { communicate } \\
\text { their role to } \\
\text { others }\end{array}$ & $\begin{array}{l}\text { Requires } \\
\text { prompting } \\
\text { some of the } \\
\text { time to } \\
\text { communicat } \\
\text { e their role } \\
\text { to others }\end{array}$ & $\begin{array}{l}\text { Ensures to } \\
\text { communicate } \\
\text { effectively to } \\
\text { the team or } \\
\text { individuals } \\
\text { details or } \\
\text { updatas } \\
\text { pertaining to } \\
\text { their role }\end{array}$ & N/A \\
\hline $\begin{array}{l}\text { Project } \\
\text { Management }\end{array}$ & $\begin{array}{l}\text { Insufficiently } \\
\text { able to help a } \\
\text { group make a } \\
\text { good design }\end{array}$ & $\begin{array}{l}\text { Lacking } \\
\text { some ability } \\
\text { to help } \\
\text { groups } \\
\text { succeed }\end{array}$ & $\begin{array}{l}\text { Demonstrates } \\
\text { ability to guide } \\
\text { design process, } \\
\text { asking for help } \\
\text { when } \\
\text { appropriate }\end{array}$ & $\begin{array}{l}\text { Does research } \\
\text { and improves } \\
\text { their skills to } \\
\text { help students }\end{array}$ \\
\hline $\begin{array}{l}\text { Conflict } \\
\text { Management }\end{array}$ & $\begin{array}{l}\text { Does not ask } \\
\text { groups about } \\
\text { problems, and } \\
\text { does not } \\
\text { resolve any } \\
\text { issues }\end{array}$ & $\begin{array}{l}\text { Does not ask } \\
\text { groups about } \\
\text { problems, } \\
\text { but solves } \\
\text { issues when } \\
\text { they are } \\
\text { brought } \\
\text { forward }\end{array}$ & $\begin{array}{l}\text { Asks groups } \\
\text { about group } \\
\text { conflicts, and } \\
\text { resolves issues } \\
\text { effectively }\end{array}$ & $\begin{array}{l}\text { Identifies } \\
\text { conflicts before } \\
\text { they are asked } \\
\text { to be involved } \\
\text { and resolves } \\
\text { issues perfectly }\end{array}$ \\
\hline
\end{tabular}




\begin{tabular}{|l|l|l|l|l|}
\hline \multicolumn{5}{|c|}{ Labs } \\
\hline Timing & $\begin{array}{l}\text { Never } \\
\text { completes the } \\
\text { lab on time or } \\
\text { takes too little } \\
\text { time to convey } \\
\text { the information } \\
\text { correctly }\end{array}$ & $\begin{array}{l}\text { Regularly } \\
\text { completes the } \\
\text { lab in a } \\
\text { reasonable time, } \\
\text { exceeding the } \\
\text { scheduled } \\
\text { completion time }\end{array}$ & $\begin{array}{l}\text { Regularly } \\
\text { completes } \\
\text { the lab on } \\
\text { schedule }\end{array}$ & N/A \\
\hline $\begin{array}{l}\text { Participant } \\
\text { Management }\end{array}$ & $\begin{array}{l}\text { Students are } \\
\text { not engaged } \\
\text { with the topics }\end{array}$ & $\begin{array}{l}\text { Some student } \\
\text { engagement; } \\
\text { could be } \\
\text { improved; low } \\
\text { motivational } \\
\text { energy }\end{array}$ & $\begin{array}{l}\text { Keeps } \\
\text { students } \\
\text { engaged } \\
\text { with the } \\
\text { topic; with } \\
\text { energetic } \\
\text { attitude }\end{array}$ & $\begin{array}{l}\text { Encourages all } \\
\text { students sto } \\
\text { actively } \\
\text { participate }\end{array}$ \\
\hline $\begin{array}{l}\text { Delivery of } \\
\text { Curriculum }\end{array}$ & $\begin{array}{l}\text { Does not } \\
\text { provide } \\
\text { minimum } \\
\text { standards } \\
\text { outlined for the } \\
\text { specific } \\
\text { training or } \\
\text { workshop }\end{array}$ & $\begin{array}{l}\text { Skips some } \\
\text { steps of training } \\
\text { but completes it } \\
\text { in a sufficient } \\
\text { manner }\end{array}$ & $\begin{array}{l}\text { Follows all } \\
\text { steps of } \\
\text { training, } \\
\text { ensuring } \\
\text { participants } \\
\text { get hands-on } \\
\text { practice }\end{array}$ & $\begin{array}{l}\text { Goes above } \\
\text { and beyond to } \\
\text { ensure } \\
\text { participants } \\
\text { understand the } \\
\text { topic }\end{array}$ \\
\hline Attitude & $\begin{array}{l}\text { Anti-social; No } \\
\text { fun }\end{array}$ & $\begin{array}{l}\text { Is upbeat and } \\
\text { friendly most of } \\
\text { the time }\end{array}$ & $\begin{array}{l}\text { Maintains a } \\
\text { positive and } \\
\text { friendly } \\
\text { attitude }\end{array}$ & $\begin{array}{l}\text { Cares about } \\
\text { projects and } \\
\text { follows up }\end{array}$ \\
\hline
\end{tabular}

